Sains Malaysiana 49(11)(2020): 2833-2846

http://dx.doi.org/10.17576/jsm-2020-4911-22

\title{
Stability Analysis of Radiotherapy Cancer Treatment Model with Fractional Derivative
}

\author{
(Analisis Kestabilan Model Rawatan Radioterapi Kanser dengan Terbitan Pecahan)
}

\author{
Musiliu Folarin Farayola, SHARIDAN SHAFIE* \& FuAADA MOHD SiAm
}

\begin{abstract}
This paper presents the condition for uniqueness, the stability analysis, and the bifurcation analysis of a mathematical model that simulates a radiotherapy cancer treatment process. The presented model was the previous cancer treatment model integrated with the Caputo fractional derivative and the Linear-Quadratic with the repopulation model. The metric space analysis was used to establish the conditions for the presence of unique fixed points for the model, which indicated the presence of unique solutions. After establishing uniqueness, the model was used to simulate the fractionated treatment process of six cancer patients treated with radiotherapy. The simulations of the cancer treatment process were done in MATLAB with numerical and radiation parameters. The numerical parameters were obtained from previous literature and the radiation parameters were obtained from reported clinical data. The solutions of the simulations represented the final volumes of tumors and normal cells. Subsequently, the initial values of the model were varied with 200 different values for each patient and the corresponding solutions were recorded. The continuity of the solutions was used to investigate the stability of the solutions with respect to initial values. In addition, the value of the Caputo fractional derivative was chosen as the bifurcation parameter. This parameter was varied with 500 different values to determine the bifurcation values. It was concluded that the solutions are unique and stable, hence the model is well-posed. Therefore, it can be used to simulate a cancer treatment process as well as to predict outcomes of other radiation protocols.
\end{abstract}

Keywords: Caputo fractional derivative; Linear-Quadratic; radiotherapy

\section{ABSTRAK}

Kertas ini membentangkan syarat keunikan, analisis kestabilan, dan analisis bifurkasi terhadap model matematik bagi simulasi proses rawatan kanser radioterapi. Model yang digunakan adalah model rawatan kanser terdahulu yang disepadukan dengan terbitan pecahan Caputo dan Kuadratik-Linear dengan model populasi semula. Analisis ruang metrik digunakan untuk menentukan syarat-syarat kehadiran titik tetap unik untuk model, yang menunjukkan kehadiran penyelesaian unik. Setelah keunikan ditentukan, model ini digunakan bagi simulasi proses rawatan berbahagi terhadap enam pesakit kanser yang dirawat dengan radioterapi. Simulasi proses rawatan kanser dilakukan dalam MATLAB dengan parameter berangka dan parameter radiasi. Parameter berangka diperoleh daripada kajian sebelumnya dan parameter radiasi diperoleh daripada data klinikal yang dilaporkan. Penyelesaian simulasi mewakili isi padu tumor terakhir dan sel normal. Selanjutnya, nilai-nilai awal model telah dipelbagaikan dengan 200 nilai yang berbeza untuk setiap pesakit dan penyelesaian yang berpadanan direkodkan. Keselanjaran penyelesaian telah digunakan untuk mengkaji kestabilan penyelesaian terhadap nilai-nilai awal. Selain itu, nilai terbitan pecahan Caputo dipilih sebagai parameter bifurkasi. Parameter ini dipelbagaikan dengan 500 nilai yang berbeza untuk menentukan nilai-nilai bifurkasi. Didapati bahawa, penyelesaian adalah unik dan stabil, maka model adalah teraju rapi. Oleh itu, model boleh digunakan bagi simulasi proses rawatan kanser serta meramalkan hasil keputusan protokol radiasi yang lain.

Kata kunci: Kuadratik-Linear; radioterapi; terbitan pecahan Caputo

\section{INTRODUCTION}

Cancer, as a result of its high mortality rate, can be regarded as the disease of the century. In a country like Malaysia, ovarian cancer is a major cause of death among women
(Lokman et al. 2017). It was reported that lung, bowel, prostate, and female breast cancer were the most common worldwide, and about 100,000 new cases of cancer were detected in Malaysia between the period of 2007-2012 
(Khalid et al. 2018). Consequently, research activities in cancer treatment have attracted scholars from multiple disciplines. Cancer treatment implies the elimination of cancerous cells from the body of the patient, with little or no damage to the normal tissues. However, the treatment of cancer is only possible if the cellular characteristics of the normal and cancerous cells are understood.

In every living organism, the healthy development of such an organism is sustained by the cellular interactions of billions of cells and the biological signals controlling such interactions. Unfortunately, when such cellular interactions collapse as a result of a disruption in the biological signals, there will be an onset of uncontrolled proliferation of cells in the organism. This uncontrolled proliferation of cells activates the cancer disease in the organism (Nawrocki \& Zubik-Kowal 2015). These uncontrolled cancerous cells can become invasive and overrun neighboring tissues, thereby forming a tumor. If the tumor is not treated medically, it will certainly lead to the death of the patient.

The clinical procedures used in treating and managing cancer patients include surgery, chemotherapy, radiotherapy, and immunotherapy. At times, two treatment procedures can be combined for a patient. In this article, the focus is only on radiotherapy. Radiotherapy is a very effective way of managing cancer, it can be used for both curative and palliative intent. It is also the most cost-effective because it accounts for only about $5 \%$ of the entire cost of treatment (Barnett et al. 2009). During radiotherapy, the rapidly proliferating cancerous cells in the cancer region are targeted and destroyed by radiation doses. However, these radiation doses cannot distinguish between cancer and normal cells during the destruction, therefore untargeted normal cells are also destroyed (Rashid et al. 2018). The elimination of cancerous cells is of benefit to the patient while the destruction of normal cells can be detrimental to the patient (Emami 2013). Mathematically, the treatment status can be measured by the population of eliminated cancer cells while the side-effects' status can be measured by the population of destroyed normal cells. Therefore, the knowledge of the decline in the populations of the cells during radiotherapy is very significant in analyzing the status of cancer treatment. Consequently, in analyzing these population dynamics, the use of mathematical models is very useful.

The use of mathematical models in cancer modeling has always taken different approaches. Some models addressed cancer at the molecular or cellular level while some used the continuum mechanics approach by treating the tumor as a system. This article focused on models applying the system approach. The pioneers of the system approach include Belostotski and Freedman (2005), they formulated a cancer treatment model based on the LotkaVolterra model. The model examined the dynamics and interaction between the normal and cancer cells under the effect of radiation. However, the model assumed that the radiation only affected the cancer cells. Subsequently, they modified the model by representing the effect of radiation on the normal cells with a perturbation constant (Freedman \& Belostotski 2009).

Liu and Yang (2014) further explored the modified model and presented a periodic cancer treatment model. For the periodic model, conditions for the coexistence of the normal and cancer cells were established. In addition, Dokuyucu et al. (2018) presented the fractional version of the model by introducing the Caputo-Fabrizio fractional derivatives into the cancer treatment model. The condition for existence and uniqueness of solutions of the fractional version was established. Awadalla et al. (2019) also presented a fractional version by introducing the Hadamard fractional derivative into the model and subsequently established the condition for the uniqueness of solutions for it. Although the previous researchers had contributed significantly to the development of the cancer treatment model, the model has remained descriptive and analytic.

The previous models, mentioned earlier, were descriptive because they described the cancer treatment process with mathematical equations. The process includes the changes in the populations of the normal and cancer cells. The decline in the cancer cells' population signifies treatment while the decline in normal cells' population will indicate the extent of side effects. For the previous models, the existence and uniqueness of solutions were established. However, the proof of existence and uniqueness of solutions for models only give analytic results. Also, some of these models used empirical data for numerical analysis. Although showing the existence of unique solutions and analyzing with empirical data is interesting mathematically, such analytic results are of little or no relevance to clinicians. In other words, the main objective of a model is to predict the outcome of a process by using initial values. As regards to cancer treatment models, the expected outcome is the final populations of the normal and cancer cells, and the initial values are the initial populations of the cells. The initial population of cancer cells can be obtained from the initial volume of the tumors. The authors of the previous models failed to provide this expected outcome in their works, hence there exists a gap between the model and its use clinically. This gap was addressed in our previous work.

In our previous work (Farayola et al. 2020a, 2020b), an improved model was used to simulate the radiotherapy treatment process of cancer patients. The improved model was obtained by introducing the Caputo fractional derivative and the Linear-Quadratic with the repopulation model into the previous model. The improved model used the Caputo fractional derivative because the MATLAB code 
FDE12.m, used for solving and simulating the fractional differential equation, only works with Caputo fractional derivative. The results of the simulations gave the final populations of cells, from which the final volumes of tumors and normal cells were obtained. However, the stability of the solutions was not ascertained. Also, it was not established if any of the model parameters causes a bifurcation in the stability of the solutions.

Therefore, in this article, the integrity of solutions obtained from simulating the cancer treatment process was investigated. This was done by first establishing the uniqueness of solutions for the improved model. Secondly, the results of simulations, of the treatment process of cancer patients, with different initial values were obtained. The parameters and clinical data of the six cancer patients used by Farayola et al. (2020a) were used to obtain a solution for each patient. Thereafter, the initial values of each patient were varied, and the new solutions were recorded. Then, the stability of the solutions was investigated. The existence, uniqueness, and stability of solutions were used to determine the well-posed characteristic of the model.

Finally, the value of the Caputo fractional derivative was chosen as the bifurcation parameter. This value was chosen because it is the most sensitive controllable model parameters (Farayola et al. 2020a, 2020b). The bifurcation parameter was varied for each patient and the bifurcation value for each patient was obtained. This value is the point at which the stability of the solutions changes and the model changes either quantitatively or qualitatively.

\section{MATERIALs AND METHODS}

This section presents the method of stability and bifurcation analysis. It contains such steps as the definition of differential operators, the formulated model, the model parameters, the proof of uniqueness, the stability of solutions, and the bifurcation analysis.

\section{DIFFERENTIAL OPERATORS}

The differential operators include the general definition of derivatives which covers classical derivative, integration, and the fractional derivative. Also defined, was the fractional derivative introduced by Caputo, as well as the fractional integral.

Definition 1 The Grunwald fractional derivative is given by (1) (Wheeler 1997). The expansion of (1) gives the general definition of a derivative given by (2).

$$
\begin{aligned}
& \quad \frac{d^{m}}{d t^{m}} f(t)=\lim _{h \rightarrow 0}\left(\frac{1-e^{-h D}}{h}\right)^{m} f(t) \quad m \in R \\
& \frac{d^{m}}{d t^{m}} f(t) \\
& =\lim _{h \rightarrow 0}\left(\frac{f(t)-m f(t-h)+\frac{m(m-1)}{2 !} f(t-2 h)-\frac{m(m-1)(m-2)}{3 !} f(t-3 h)+. .+f(t-m h)}{h^{m}}\right)
\end{aligned}
$$

The value of $m$ in (1) and (2), in which (2) is an expansion of (1), determines the class of the derivative. When $m$ is a positive integer, then the derivative becomes a classical derivative with the property of locality. If $m$ is a negative integer, the derivative becomes integral and has the property of non-locality. Lastly, when $m$ is a fraction, the derivative becomes a fractional derivative with the property of non-locality. The main advantage of the fractional derivative is its non-locality where the derivative covers the entire points in the interval, unlike classical derivatives where the derivative only covers a limited number of points. Since cancer treatment by radiotherapy is a process that covers several fractionated dose schedules over an interval, it is imperative to use the fractional derivative that takes into consideration all the points within the interval.

Furthermore, the question of the physical meaning or geometrical interpretation of fractional derivative has been an open problem for many years. This question was correctly explained by Du et al. (2013) that the real physical meaning of fractional derivative is that the fractional-order is an index or measure of the memory of a process. When the order is zero, nothing is memorized, this gives the function. But when the order is 1, nothing is forgotten (instantaneous change), this gives the classical or integer-order derivative. Many physical processes operate between these two extremes, for instance, viscoelastic materials operate between elasticity (order of zero, which obeys Hooke's law) and viscosity (order of 1, which obey Newton's vicious law). Therefore, a viscoelastic material should be modeled with a fractional-order between 0 and 1. This explanation was corroborated with experimental results. Also, Du et al. (2013) showed how this fractionalorder indicates the memory pattern in biological and psychological processes, which was also corroborated with experimental results. Since the cancer treatment process is a biological process incorporating memory over an interval, then it is more correct to model it with a fractional derivative. In the numerical simulations done in this article, the interval was interpreted with 0 to $T$, while the fractional-order signifies the memory of the process. However, if a classical derivative was used, the interval will still be interpreted with 0 to $T$, but the memory of the process will be incorrect because the process is not instantaneous.

There are various definitions of fractional derivatives, but the definition of Caputo was used in this article.

Definition 2 The Caputo fractional derivative is given by (3) (Abuasad \& Hashim 2018; Caputo \& Fabrizio 2015)

$$
{ }_{0}^{C} D_{t}^{\mu}(f(t))=\frac{1}{\Gamma(1-\mu)} \int_{0}^{t} \frac{d f(x)}{d x} \frac{1}{(t-x)^{\mu}} d x, \quad 0<\mu<1
$$

where $f(t) \in H^{1}(0, b), H^{1}$ is a Sobolev space. 
Definition 3 The fractional integral of order $\mu$ is given by (4) (Losada \& Nieto 2015)

$$
\begin{gathered}
{ }^{C F} I^{\mu} f(t)=\frac{2(1-\mu)}{(2-\mu) M(\mu)} f(t)+\frac{2 \mu}{(2-\mu) M(\mu)} \int_{0}^{t} f(s) d s, \\
0<\mu<1, t \geq 0
\end{gathered}
$$

where $M(\mu)$ is the normalization function such that $M(0)=M(1)=1$

The Caputo-Fabrizio fractional integral (4) was obtained by using the Caputo-Fabrizio fractional derivative, which was an exponential function of the Caputo fractional derivative.

\section{THE MATHEMATICAL MODEL}

This section presents the formulated model to be analyzed. The cancer treatment model represents the biological process of radiotherapy. During radiotherapy, the populations of cells are affected by the proliferation of cells which increases their populations, the competition for resources between cancer and normal cells which reduces their populations, and the effect of radiation doses which also decreases their populations. After some days during treatment, the cancer cells will start repopulating which adds to the population of the cancer cells. The model parameters were used to represent the biological processes. The model variables were the populations of the cells and the time for treatment. The previous cancer treatment model and the improved model are given in the following subsections.

\section{THE PREVIOUS CANCER TREATMENT MODEL}

The previous cancer treatment model assumed that cancer and normal cells are in the same region competing for body resources. Let the populations of normal and cancer cells be denoted by $u_{1}(t)$ and $u_{2}(t)$, respectively, the model is given by (5) and (6) (Belostotski \& Freedman 2005; Freedman \& Belostotski 2009).

$$
\begin{aligned}
& \frac{d}{d t}\left(u_{1}(t)\right)=\alpha_{1}\left(1-\frac{u_{1}}{K_{1}}\right) u_{1}-\beta_{1} u_{2} u_{1}-\varepsilon D(t) u_{1} \\
& \frac{d}{d t}\left(u_{2}(t)\right)=\alpha_{2}\left(1-\frac{u_{2}}{K_{2}}\right) u_{2}-\beta_{2} u_{1} u_{2}-D(t) u_{2}
\end{aligned}
$$

where $u_{1}, u_{2}$ are the populations of normal and cancer cells respectively; $\alpha_{1}, \alpha_{2}$ are the respective proliferation coefficients; $K_{1}, K_{2}$ are the respective carrying capacities; $\beta_{1}, \beta_{2}$ are the respective competition coefficients; $D(t)$ is the strategy of radiotherapy; and is the perturbation constant.
THE IMPROVED CANCER TREATMENT MODEL

The improved model was obtained by integrating the Caputo fractional derivative and the Linear-Quadratic with the repopulation model into the previous cancer treatment model. The integrated Caputo fractional derivative gave the changes in the populations of the cells over the entire treatment time while the LinearQuadratic with the repopulation model accounted for the population decline of the cells as a result of radiation. The improved model is given by (7) and (8) (Farayola et al. 2020a).

$$
\begin{array}{r}
{ }_{0}^{C} D_{T}^{\mu}\left(u_{1}(t)\right)=\alpha_{1}\left(1-\frac{u_{1}}{K_{1}}\right) u_{1}-\beta_{1} u_{2} u_{1} \\
-\varepsilon\left[\alpha s(t)+2 \beta s(t)\left(\int_{0}^{t} \exp (-\lambda(t-\tau)) s(\tau) d \tau\right)\right] u_{1} \\
{ }_{0}^{C} D_{T}^{\mu}\left(u_{2}(t)\right)=\alpha_{2}\left(1-\frac{u_{2}}{K_{2}}\right) u_{2}-\beta_{2} u_{1} u_{2}- \\
{\left[\alpha s(t)+2 \beta s(t)\left(\int_{0}^{t} \exp (-\lambda(t-\tau)) s(\tau) d \tau\right)-\frac{\mathrm{h} 2}{T_{P}} \frac{\left(T_{d}-T_{K}\right)}{T_{d}}\right] u_{2}}
\end{array}
$$

where ${ }_{0}^{C} D_{T}^{\mu}$ is the Caputo fractional derivative; $\alpha$ is the yield rate for lethal lesions; $\beta$ is the yield rate for sublethal lesions; $T_{d}$ is the total time of treatment (number of days); $T_{K}$ is the "kick-off" time for the repopulation of the cancer cells; $T_{P}$ is the effective doubling time of the cancer cells; $s(t)$ is the time-varying fractionated dose rate; $\lambda$ is the repair time constant defined as $\frac{\ln (2)}{T_{1 / 2}} ; T$ is the total time for radiotherapy, and $T_{1 / 2}$ is the half time for repair.

The explanation of these model parameters for the cancer treatment process was summarised in the following subsection.

\section{THE MODEL PARAMETERS}

Biologically, the two cells proliferate but the cancer cells proliferate much more than the normal cells. The proliferation rate, or coefficients, of the normal and cancer cells, were represented by $\alpha_{1}$ and $\alpha_{2}$. However, the proliferation of cells is bounded by the population carrying capacities represented by $K_{1}$ and $K_{2}$. Also, the two cells compete for body resources which causes a reduction in the populations. This was represented by the competition coefficients $\beta_{1}$ and $\beta_{2}$. The cells' population decay due to radiation was represented by the linear-quadratic with the repopulation model (Bertuzzi et al. 2013; Fowler 2006; Jones 1999; Lee et al. 1995; O'Rourke et al. 2009) with the appropriate radiation parameters.

The radiation parameters include the administered fractionated radiation dose represented by $s(t)$ measured in Grays (Gy), the yield rate of cells destroyed by singletrack action of radiation (lethal lesions) represented by $\alpha$, 
the yield rate of cells destroyed by double-track action of radiation (sub-lethal lesions) represented by $\beta$, the repair time of sub-lethal lesions in between fractionated doses represented by $\lambda$, the half time for the repair time represented by $T_{1 / 2}$, the number of days for the treatment represented by $T_{d}$, the effective doubling time which determines the proliferation coefficient of cancer cells represented by $T_{p}$, the number of days before the cancer cells will start repopulating represented by $T_{K}$, and perturbation constant that accounted for the reduced radiation effect on the normal cells represented by $\varepsilon$.

In continuation, the model variables are the populations of the cells and the time for treatment. The time for treatment includes the time for the administration of a fractionated dose represented by $t$, and summation of these fractionated dose's time represented by $T$. The populations of cells were represented by $u_{1}(t)$ and $u_{2}(t)$. The initial populations of the cells can be obtained from the volumes of the tumors because $1 \mathrm{~cm}^{3}$ contains approximately 1 billion cells (Benzekry et al. 2014). The final populations of cancer and normal cells are the expected solutions of the improved model, equation (7) and (8), which can be used to obtain the final volumes of the tumors and the normal cells. In the next sub-section, the condition for the uniqueness of the solution was established.

\section{UNIQUENESS OF SOLUTIONS}

The model equations (7) and (8) were written in a simplified form given by (9) and (10).

$$
\begin{gathered}
{ }_{0}^{C} D_{T}^{\mu}\left(u_{1}(t)\right)=\alpha_{1}\left(1-\frac{u_{1}}{K_{1}}\right) u_{1}-\beta_{1} u_{2} u_{1}-\varepsilon \chi\left(u_{1}, t\right) \\
{ }_{0}^{C} D_{T}^{\mu}\left(u_{2}(t)\right)=\alpha_{2}\left(1-\frac{u_{2}}{K_{2}}\right) u_{2}-\beta_{2} u_{1} u_{2}-\chi\left(u_{2}, t\right)
\end{gathered}
$$

Since (9) and (10) are similar, a general form of the equations given by (11) was used for the proof.

$$
\begin{aligned}
& { }_{0}^{C} D_{T}^{\mu}\left(u_{i}(t)\right)=\alpha_{i}\left(1-\frac{u_{i}}{K_{i}}\right) u_{i}-\beta_{i} u_{j} u_{i}-\varepsilon_{i} \chi\left(u_{i}, t\right), i=1,2 ; j=1,2 ; \\
& \varepsilon_{i}=1 \text { when } i=2
\end{aligned}
$$

where

$$
\begin{gathered}
\chi\left(u_{1}, t\right)=\left[\alpha s(t)+2 \beta s(t)\left(\int_{0}^{t} \exp (-\lambda(t-\tau)) s(\tau) d \tau\right)\right] u_{1}, \text { and } \\
\chi\left(u_{2}, t\right)=\left[\alpha s(t)+2 \beta s(t)\left(\int_{0}^{t} \exp (-\lambda(t-\tau)) s(\tau) d \tau\right)-\frac{\ln 2}{T_{P}} \frac{\left(T_{d}-T_{K}\right)}{T_{d}}\right] u_{2}
\end{gathered}
$$

Lemma $1 u_{i}(t) \in X,(X, d)$ is a complete metric space.

Proof In the model, final populations of the cells $u_{i}(t)$ are bounded by the carrying capacities $u_{i}(t) \leq K_{i}$. Also, the results of numerical simulations showed that the final populations, $u_{i}(t)$, are uniformly continuous and convergent (Farayola et al. 2020a, 2020b). Since the populations, $u_{i}(t)$, are uniformly continuous, convergent, and bounded. This indicates that the functions converge to limits in $(X, d)$. Therefore, $(X, d)$ is a complete metric space.

Theorem 1 Let $(X, d)$ be a complete metric space and $T: X \rightarrow X$ be a contraction mapping there exists $0 \leq k<1$ such that $d\left(T x_{1}, T x_{2}\right) \leq k d\left(x_{1}, x_{2}\right)$ for all $x_{1}, x_{2} \in X$. Then $T$ has a unique fixed point.

The equation (11) can be written as a fixed-point equation $T u=u$ where $T$ is the integral operator. In this case, $T$ was the fractional integral.

Hypothesis If $T$ has a unique fixed point $u \in X$, then (11) has a unique solution $u_{i}(t)$ (Borisut et al. 2018).

Proof By using (4), (12) was obtained

$$
\begin{gathered}
T u(t)={ }^{C F} I^{\mu} u(t)=\frac{2(1-\mu)}{(2-\mu) M(\mu)} u(t)+\frac{2 \mu}{(2-\mu) M(\mu)} \int_{0}^{t} u(s) d s \\
0<\mu<1, t \geq 0
\end{gathered}
$$

For simplicity, we chose a kernel, (13), to represent the function of $u(t)$ and $t$ in (11).

$$
f\left(t, u_{i}(t)\right)=\alpha_{i}\left(1-\frac{u_{i}}{K_{i}}\right) u_{i}-\beta_{i} u_{j} u_{i}-\varepsilon_{i} \chi\left(u_{i}, t\right)
$$

Therefore, (12) became (14)

$$
T u(t)=\frac{2(1-\mu)}{(2-\mu) M(\mu)} f\left(t, u_{i}(t)\right)+\frac{2 \mu}{(2-\mu) M(\mu)} \int_{0}^{t} f\left(s, u_{i}(s)\right) d s
$$

By considering two solutions for (14), $T u_{1}(t)$ and $T u_{2}(t)$ with metric given by (15)

$$
\begin{gathered}
d\left(T u_{1}(t), T u_{2}(t)\right)=\left|T u_{1}(t)-T u_{2}(t)\right| \\
\left|T u_{1}(t)-T u_{2}(t)\right|=\mid\left[\frac{2(1-\mu)}{(2-\mu) M(\mu)} f\left(t, u_{1 i}(t)\right)+\frac{2 \mu}{(2-\mu) M(\mu)} \int_{0}^{t_{1}} f\left(s, u_{1 i}(s)\right) d s\right] \\
-\left[\frac{2(1-\mu)}{(2-\mu) M(\mu)} f\left(t, u_{2 i}(t)\right)+\frac{2 \mu}{(2-\mu) M(\mu)} \int_{0}^{t_{2}} f\left(s, u_{2 i}(s)\right) d s\right] \\
\left|T u_{1}(t)-T u_{2}(t)\right| \leq \frac{2(1-\mu)}{(2-\mu) M(\mu)}\left|f\left(t, u_{1 i}(t)\right)-f\left(t, u_{2 i}(t)\right)\right| \\
+\frac{2 \mu}{(2-\mu) M(\mu)}\left|\int_{0}^{t_{1}} f\left(s, u_{1 i}(s)\right) d s-\int_{0}^{t_{2}} f\left(s, u_{2 i}(s)\right) d s\right|
\end{gathered}
$$


By choosing $L$ as the Lipschitz constant, the inequality (17) became (18)

$$
\begin{gathered}
\left|T u_{1}(t)-T u_{2}(t)\right| \leq \frac{2(1-\mu)}{(2-\mu) M(\mu)} L\left|u_{1 i}(t)-u_{2 i}(t)\right|+\frac{2 \mu}{(2-\mu) M(\mu)} L\left|u_{1 i}(t)-u_{2 i}(t)\right| \\
\left|T u_{1}(t)-T u_{2}(t)\right| \leq\left[\frac{2(1-\mu)}{(2-\mu) M(\mu)} L+\frac{2 \mu}{(2-\mu) M(\mu)} L\right]\left|u_{1 i}(t)-u_{2 i}(t)\right|
\end{gathered}
$$

Let $k=\left[\frac{2(1-\mu)}{(2-\mu) M(\mu)} L+\frac{2 \mu}{(2-\mu) M(\mu)} L\right]$, therefore, $k$ is also a Lipschitz constant in (20) and (21).

$$
\begin{gathered}
\left|T u_{1}(t)-T u_{2}(t)\right| \leq k\left|u_{1 i}(t)-u_{2 i}(t)\right| \\
d\left(T u_{1}(t), T u_{2}(t)\right) \leq k d\left(u_{1 i}(t), u_{2 i}(t)\right)
\end{gathered}
$$

When $0 \leq k<1, T$ has a unique fixed point $u$, and (11) has a unique solution $u_{i}(t)$. Therefore, if the condition $k$ is satisfied, the model (7) and (8) will have unique solutions which are the final populations of the cells. In the next sub-section, the stability of the solutions was established.

\section{STABILITY OF SOLUTION}

The stability of solutions with respect to initial values was ascertained by solving the model (7) and (8) with different initial values. The values used for the computation were obtained from previous literature. The values of the proliferation coefficients $\alpha_{1}, \alpha_{2}$, the competition coefficients $\beta_{1}, \beta_{2}$, and the perturbation constant $\varepsilon$ were obtained from Belostotski and Freedman (2005). The values of radiation parameters were obtained from reported clinical data of six patients treated with radiotherapy. The obtained values were fractionated dose $s(t)$ and the radiosensitivity values $\alpha, \beta$ from Belfatto et al. (2016). The repopulation parameters $T_{K}$ and the rate of repopulation were obtained from Fowler (2006). It was assumed that each fractionated treatment $(t)$ took $15 \mathrm{~min}$ and the summation of the fractionated times gave $T$. The repair rate constant $\lambda$ was obtained from Bertuzzi et al. (2013). The initial populations of cells were obtained by scaling the initial tumor volumes of the six patients (Belfatto et al. 2016). It was assumed that the initial populations of normal and cancer cells were equal.

The values of the numerical values of the parameters were presented in Table 1. Also, Table 2 gave a summary of the clinical data of the patients and the scaled values of the initial populations of the cells. Finally, Table 3 gave the results of each simulation of the model which provided the scaled final populations of the cells. The actual populations of cells can be obtained by multiplying the scaled populations by $1 \times 10^{11}$ and when the result is divided by 1 billion $\left(1 \times 10^{9}\right)$ cells, the answer is the final volumes of tumors and normal cells. The simulated final volumes of tumors obtained from Table 3 were compared with the reported final volumes of the tumors in Table 2. The results coincided with Patients 2 and 4 while the other patients had errors $0.01 \mathrm{~cm}^{3}$. After obtaining simulated results for each patient, the initial populations of cells for each patient were varied and the corresponding solutions were obtained, and the computational process was presented in the next subsection.

TABLE 1. Numerical parameters

\begin{tabular}{cc}
\hline Numerical parameters & Numerical values \\
\hline$\alpha_{1}$ & $9.7041 \times 10^{-4}$ \\
$\alpha_{2}$ & 0.3396 \\
$\beta_{1}$ & 0.0433 \\
$\beta_{2}$ & 0.2385 \\
$K_{1}$ & 1 \\
$K_{2}$ & 1 \\
$\varepsilon$ & 0.0008 \\
$\alpha\left(G y^{-1}\right)$ & 0.3 \\
$\beta\left(G y^{-2}\right)$ & 0.03 \\
$t$ (mins) & 15 \\
$T_{1 / 2}$ (mins) & 15 \\
$T_{K}$ (days) & 28 \\
Rate of repopulation & 0.6 \\
\hline
\end{tabular}


TABLE 2. Clinical data of cancer patients treated with radiotherapy

\begin{tabular}{ccccccc}
\hline Patient & Initial vol. $\mathrm{cm}^{3}$ & Final vol. $\mathrm{cm}^{3}$ & Fractionated dose (Gy) & Number of fractions & Total dose (Gy) & Initial pop. \\
\hline 1 & 24.1 & 3.59 & 2 & 25 & 50 & 0.241 \\
2 & 17.4 & 8.61 & 2 & 25 & 50 & 0.174 \\
3 & 28.4 & 5.67 & 1.8 & 25 & 45 & 0.284 \\
4 & 18.8 & 4.36 & 1.8 & 28 & 50.4 & 0.188 \\
5 & 30.6 & 5.74 & 1.8 & 28 & 50.4 & 0.306 \\
6 & 12.6 & 6.11 & 1.8 & 25 & 45 & 0.126 \\
\hline
\end{tabular}

TABLE 3. Radiation parameters and results of each simulation

\begin{tabular}{ccccccc}
\hline Radiation parameters & Patient 1 & Patient 2 & Patient 3 & Patient 4 & Patient 5 & Patient 6 \\
\hline$s(t)$ & 2 & 2 & 1.8 & 1.8 & 1.8 & 1.8 \\
No. of fractions & 25 & 25 & 25 & 28 & 28 & 25 \\
$T$ (mins) & 375 & 375 & 375 & 420 & 420 & 375 \\
$\mu$ & 0.1993 & 0.1863 & 0.1588 & 0.1532 & 0.1566 & 0.1508 \\
$T_{d}$ (days) & 35 & 35 & 35 & 38 & 38 & 35 \\
Initial $\mu_{1}$ & 0.241 & 0.174 & 0.284 & 0.188 & 0.306 & 0.126 \\
Final $\mu_{1}$ & 0.0358 & 0.0861 & 0.0568 & 0.0436 & 0.0575 & 0.0612 \\
Initial $\mu_{2}$ & 0.241 & 0.174 & 0.284 & 0.188 & 0.306 & 0.126 \\
Final $\mu_{2}$ & 0.2387 & 0.1729 & 0.2817 & 0.1868 & 0.3033 & 0.1255 \\
\hline
\end{tabular}

\section{COMPUTATIONAL PROCESS}

Four arrays with dimensions $(200,1)$ were created in MATLAB for each patient. The first two arrays were used to store the different initial populations of the normal and cancer cells. The initial populations of cells of the patients were varied as follows; Patient $1(0.231-0.251)$, Patient 2 (0.164 - 0.184), Patient 3 (0.274 - 0.294), Patient 4 (0.178 - 0.198), Patient 5 (0.296 - 0.316), and Patient 6 $(0.116-0.316)$. The step size was 0.0001 in each case. The model, equations (7) and (8) were solved in MATLAB with each initial population. The Caputo fractional derivative in (7) and (8) was solved with the fractional differential equation code (FDE12.m) (Diethelm 2003; Diethelm \& Freed 1998; Diethelm et al. 2004; Garrappa 2010; Hairer et al. 1985). The other parameters were left unchanged for each simulation. The solutions for each simulation were stored in the other two arrays. The process was repeated for each patient. Therefore, each patient had 200 solutions (final populations of cells). The results are presented in Figures 1-6.

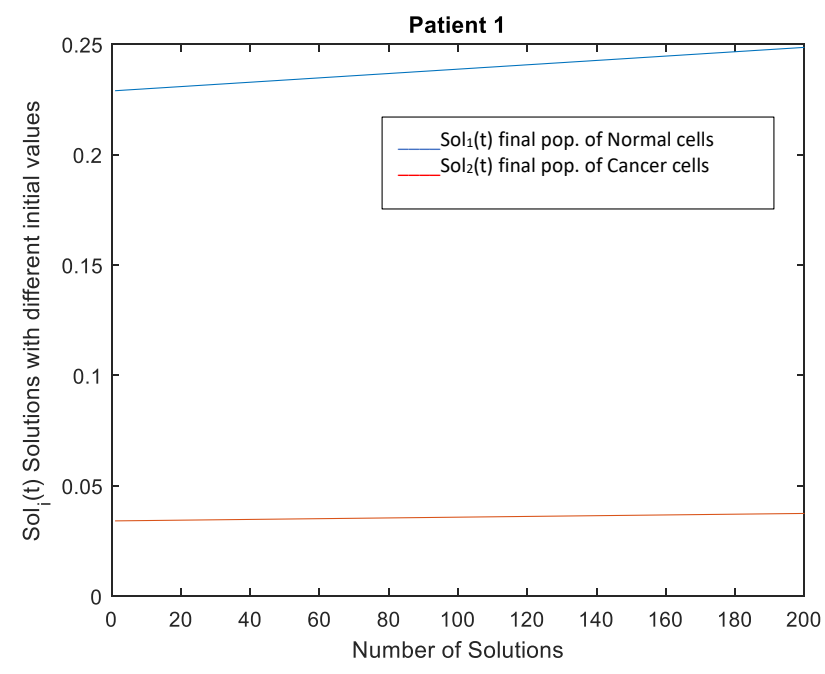

FIGURE 1. Solutions with initial populations $(0.231-0.251)$ 


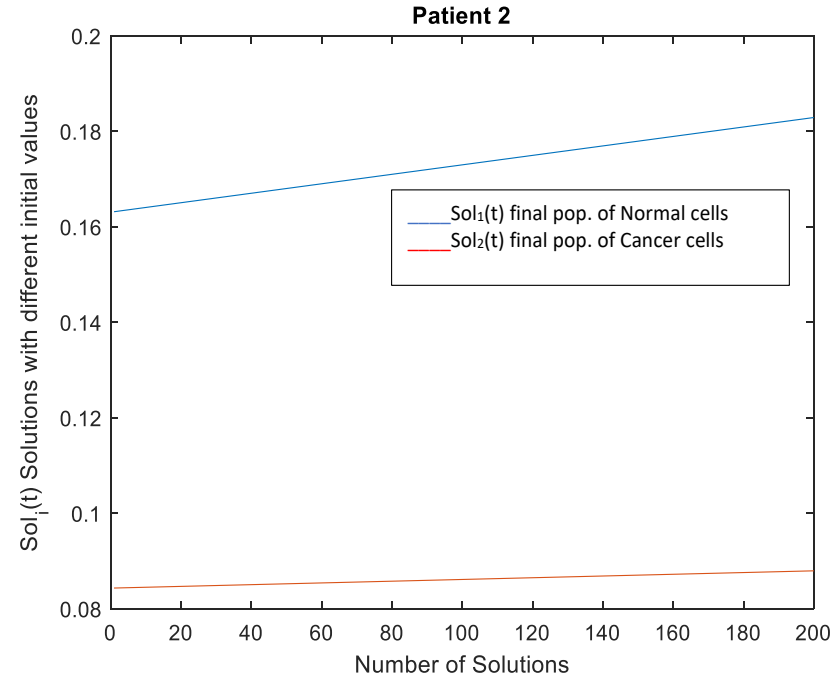

FIGURE 2. Solutions with initial populations $(0.164-0.184)$

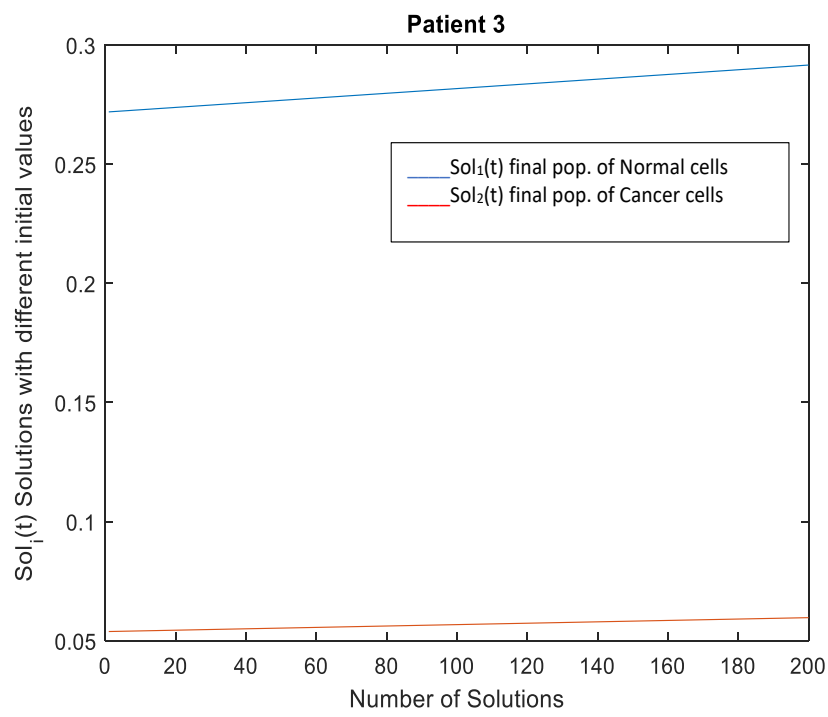

FIGURE 3. Solutions with initial populations (0.274 - 0.294)

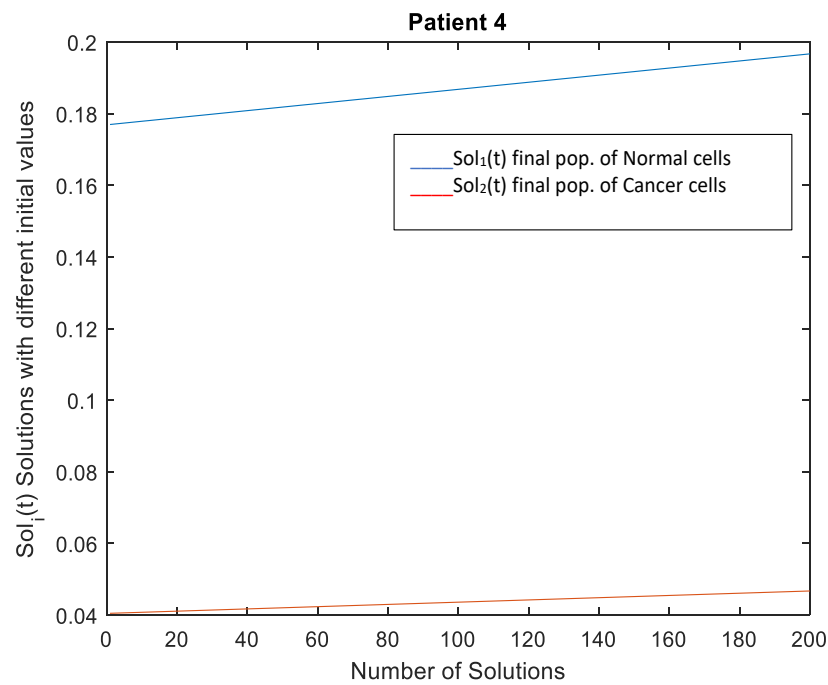

FIGURE 4. Solutions with initial populations $(0.178-0.198)$ 


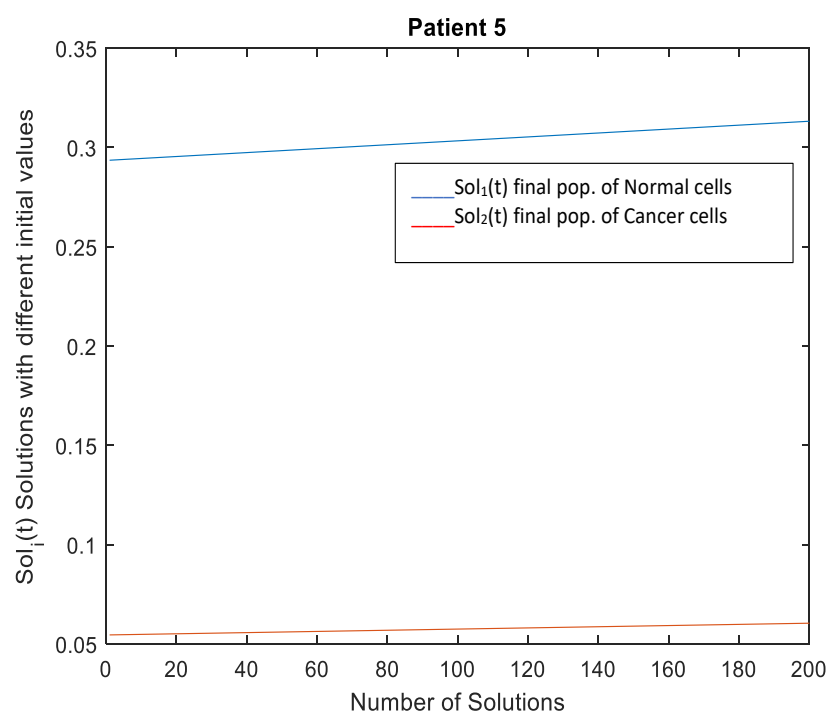

FIGURE 5. Solutions with initial populations (0.296 - 0.316)

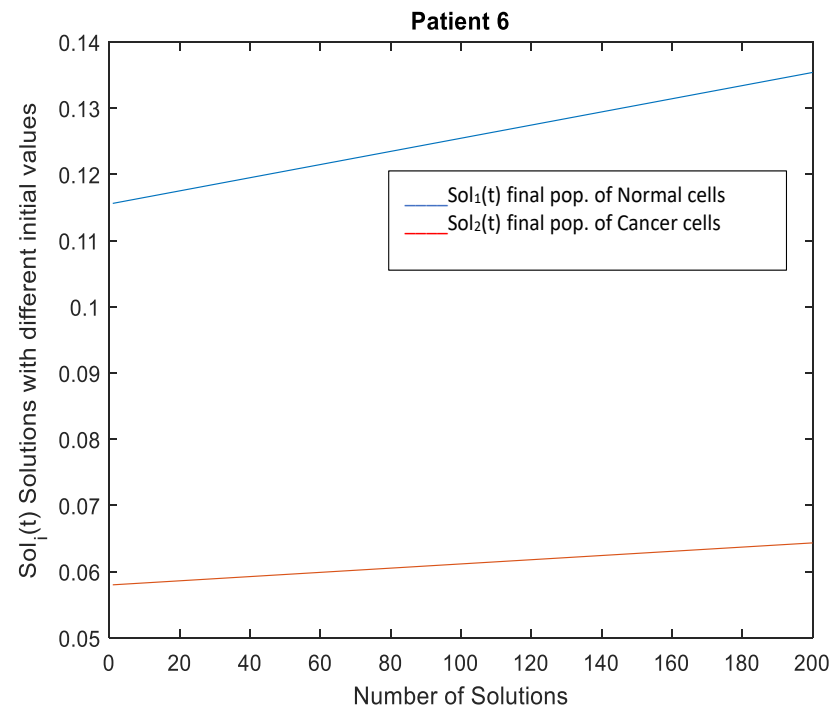

FIGURE 6. Solutions with initial populations $(0.116-0.316)$

The results of the simulations showed the solutions (final populations of cells) were continuous with respect to initial values. This implies that the solutions obtained from the model (7) and (8) were stable with respect to initial values.

\section{BIFURCATION ANALYSIS}

Apart from the initial values, the solutions are also affected by changes in the parameters. Therefore, it is important to perform a bifurcation analysis by choosing a bifurcation parameter. The bifurcation parameter is the one that causes a change in the stability of the solutions either qualitatively or quantitatively and the bifurcation value is the point at which the stability changes. The chosen bifurcation parameter was the value of the Caputo fractional derivative because it is the most sensitive controllable model factor (Farayola et al. 2020a, 2020b). The other parameters were not changed because the radiation parameters were clinical data while the numerical parameters depend on the type of cancer. 
The bifurcation analysis was done numerically by simulating different solutions with different values of the Caputo fractional derivative. The computation was also done in MATLAB in a similar way as the stability analysis. The bifurcation parameter was changed 500 times which implied 500 solutions for each patient. The changes were as follows; Patient 1 (0.1801 - 0.2300), Patient 2 (0.1701
- 0.2200), Patient 3 (0.1401 - 0.1900), Patient 4 (0.1401 $0.1900)$, Patient 5 (0.1401 - 0.1900), and Patient 6 (0.1401 - 0.1900). The step size for each patient was 0.0001 . The bifurcation values for the patients were as follows; Patient 1 (0.2029), Patient 2 (0.2016), Patient 3 (0.1621), Patient 4 (0.1562), Patient 5 (0.1595), and Patient 6 (0.1577). The results of the simulations are presented in Figures 7-12.

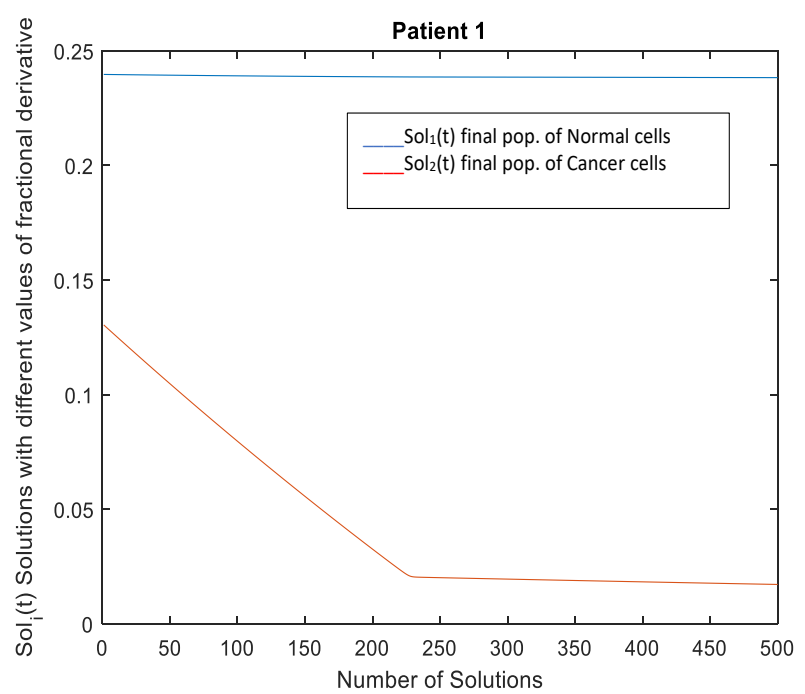

FIGURE 7. Solutions with Caputo fractional derivatives (0.1801 - 0.2300)

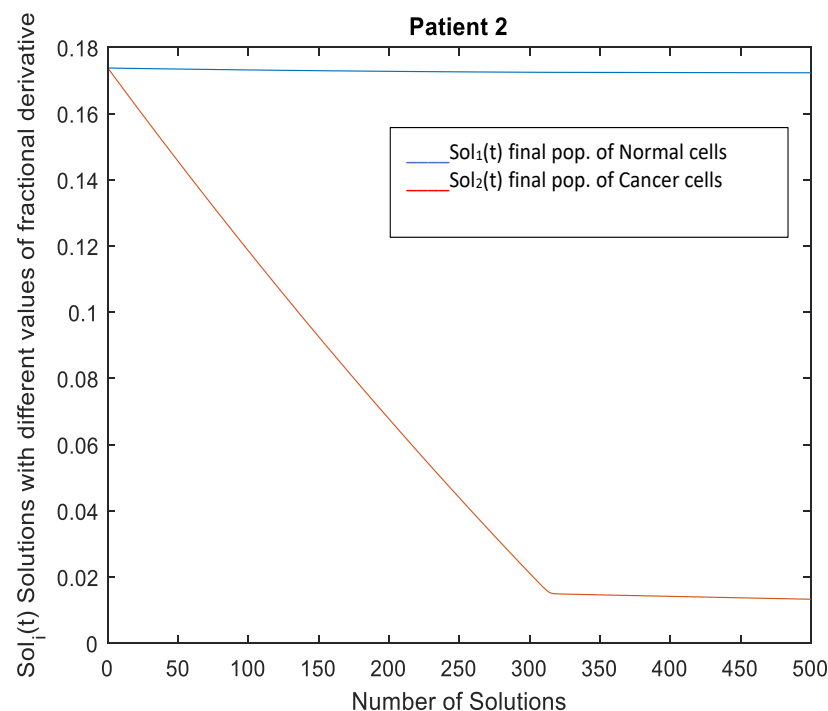

FIGURE 8. Solutions with Caputo fractional derivatives (0.1701 - 0.2200) 


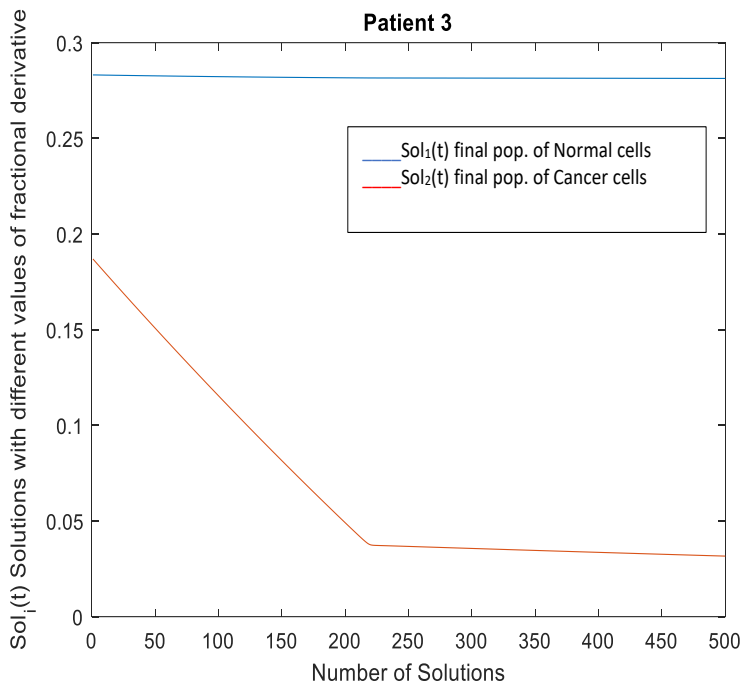

FIGURE 9. Solutions with Caputo fractional derivatives (0.1401 - 0.1900)

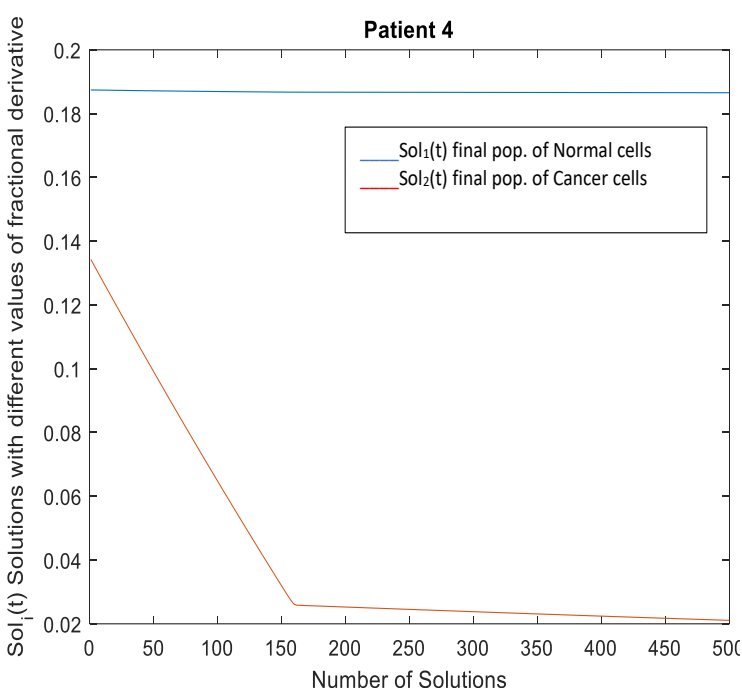

FIGURE 10. Solutions with Caputo fractional derivatives $(0.1401-0.1900)$

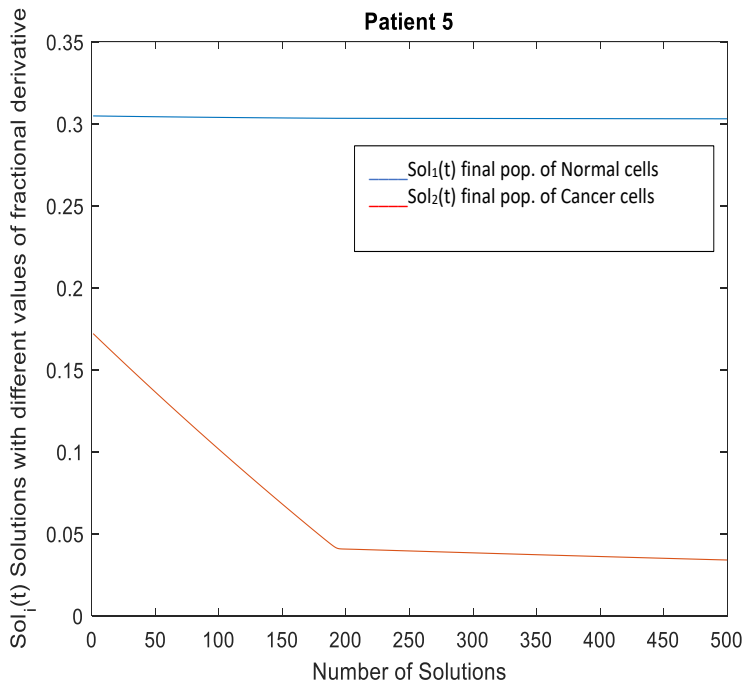

FIGURE 11. Solutions with Caputo fractional derivatives (0.1401 - 0.1900) 


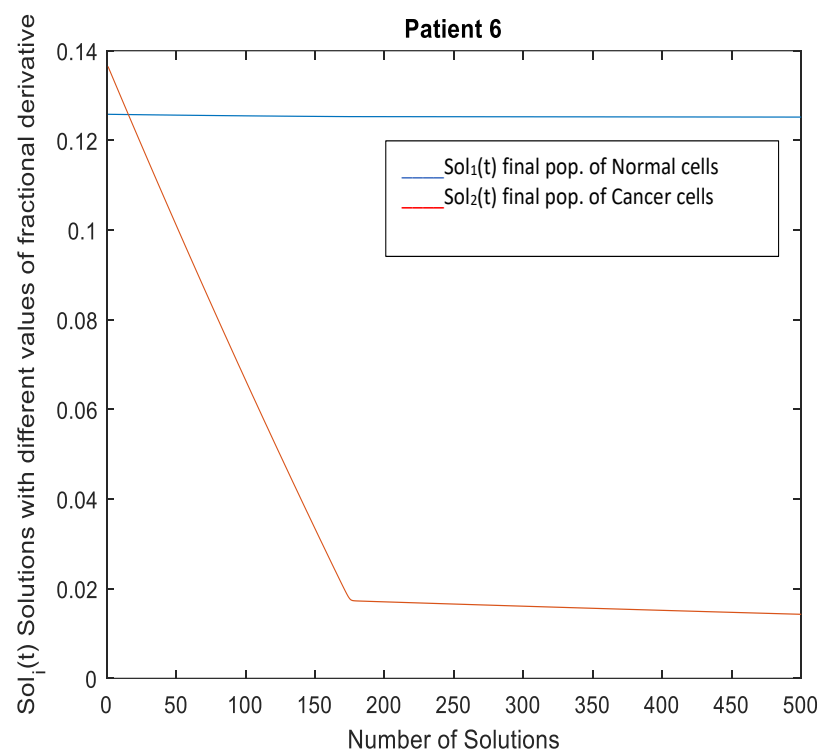

FIGURE 12. Solutions with Caputo fractional derivatives $(0.1401-0.1900)$

The results showed that the bifurcation parameter only affected the solutions for the cancer cells. Before the bifurcation value, the solutions exhibited stability. However, after the bifurcation value, the quality of solutions for the cancer cells became unreliable and the solutions gave the final populations of cancer cells as approaching zero. Therefore, the model is only reliable qualitatively before the bifurcation values. In order to avoid bifurcation values, a regression equation that approximates good values for the Caputo fractional derivative was presented in our previous work (Farayola et al. 2020a).

\section{RESULTS AND DISCUSSION}

The cancer treatment by radiotherapy process is aimed at reducing the population of cancer cells while sparing the normal cells. However, treatments are mostly partial and there is always an incomplete elimination of the cancer cells with an unintended elimination of some normal cells. The use of the improved cancer treatment model can be of great use because the populations of the destroyed normal and cancer cells can be simulated. The simulated results can be used to determine the expected final volumes of tumors and normal cells. The model was used to simulate the cancer treatment process of six patients with the results presented in Table 3. By converting the simulated final populations of cells in Table 3 into volumes, the final volumes of tumors of the patients were $3.58 \mathrm{~cm}^{3}, 8.61 \mathrm{~cm}^{3}$, $5.68 \mathrm{~cm}^{3}, 4.36 \mathrm{~cm}^{3}, 5.75 \mathrm{~cm}^{3}$, and $6.12 \mathrm{~cm}^{3}$. Also, the final volumes of normal cells were $23.87 \mathrm{~cm}^{3}, 17.29 \mathrm{~cm}^{3}, 28.17$ $\mathrm{cm}^{3}, 18.68 \mathrm{~cm}^{3}, 30.33 \mathrm{~cm}^{3}$, and $12.55 \mathrm{~cm}^{3}$. The simulated final volumes were compared with the reported clinical data in Table 2, and they coincided with the clinical data for Patients 2 and 4 while the other patients had an error of $0.01 \mathrm{~cm}^{3}$ each. Furthermore, the percentage of the destroyed cancer cells signified the mathematical interpretation of cancer treatment while the percentage of the destroyed normal cells signified the extent of sideeffects. Therefore, the model can be used to analyze the treatment process and predict the outcome of treatment protocols. However, it is also important to investigate the integrity of the solutions of the model.

After establishing the conditions for the uniqueness of solutions for the model, it is correct to conclude that the results from the simulations were unique solutions. These unique solutions were also shown to be stable with respect to initial values. This implied that changes in the initial values will not increase the errors in the output. Therefore, the initial populations of cells (initial volume of tumors) will not compromise the stability of the model. This analysis showed that the improved model, (7) and (8), is well-posed. This is because the solutions obtained from the model are unique and stable. As a result, the model can simulate a cancer treatment process and can be used to analyze the extent of treatment and side effects of patients.

Furthermore, the bifurcation analysis performed on the most sensitive controllable model factor, which was the Caputo fractional derivative, showed that at 
the bifurcation values the model was no longer reliable qualitatively. The solutions obtained for the final volumes of the tumors of the patients at the bifurcation values were as follows; $2.06 \mathrm{~cm}^{3}, 1.51 \mathrm{~cm}^{3}, 3.74 \mathrm{~cm}^{3}, 2.59 \mathrm{~cm}^{3}$, $4.07 \mathrm{~cm}^{3}$, and $1.74 \mathrm{~cm}^{3}$. These values were not in line with the clinical data. After the bifurcation values, the model's solutions for the final populations of cancer cells approached zero. Therefore, the integrity of the model is not guaranteed after the bifurcation values. Also, the bifurcation parameter did not affect the solutions of the normal cells.

\section{CONCLUSION}

In this article, the improved cancer treatment model was presented. The presented model was formulated by integrating the Caputo fractional derivative and the Linear-Quadratic with the repopulation model into the previous cancer treatment model. The biological interpretation of the model parameters and variables were also presented. Thereafter, the condition for the uniqueness of solutions for the model was established. The model was then used to simulate the treatment process of six cancer patients treated with radiotherapy. The model parameters and variables were obtained from previous literature. From the results of the simulations, the final volumes of tumors and normal cells were obtained. The stability of these solutions with respect to initial values was ascertained. Furthermore, the bifurcation analysis of the model was done with the use of a bifurcation parameter.

The chosen bifurcation parameter was the value of the Caputo fractional derivative. It was shown that the model exhibited stability before the bifurcation values. After these values, the quality of the solutions from the model was no longer guaranteed. Finally, it was concluded that the improved model is well-posed because the solutions are unique and stable. Therefore, the model can simulate a cancer treatment process and predict the outcomes of other radiation protocols.

\section{ACKNOWLEDGEMENTS}

The authors would like to acknowledge the Ministry of Education (MOE), Malaysia and Research Management center-UTM, Universiti Teknologi Malaysia (UTM) for the financial support through vote numbers 5F004, 5F116, 07G70, 07G72, 07G76, 07G77 and 17J98 for this research.

\section{REFERENCES}

Abuasad, S. \& Hashim, I. 2018. Homotopy decomposition method for solving higher-order time- fractional diffusion equation via modified beta derivative. Sains Malaysiana 47(11): 2899-2905.

Awadalla, M., Yameni, Y. \& Abuassba, K. 2019. A new fractional model for the cancer treatment by radiotherapy using the Hadamard fractional derivative. Online Mathematics 1(2): 14-18.
Barnett, G.C., West, C.M.L., Dunning, A.M., Elliott, R.M., Coles, C.E., Pharoah, P.D.P. \& Burnet, N.G. 2009. Normal tissue reactions to radiotherapy: Towards tailoring treatment dose by genotype. Nature Reviews Cancer 9(2): 134-142.

Belfatto, A., Riboldi, M., Ciardo, D., Cattani, F., Cecconi, A., Lazzari, R., Jereczek-Fossa, B.A., Orecchia, R., Baroni, G. \& Cerveri, P. 2016. Kinetic models for predicting cervical cancer response to radiation therapy on individual basis using tumor regression measured in vivo with volumetric imaging. Technology in Cancer Research \& Treatment 15(1): 146-158.

Belostotski, G. \& Freedman, H.I. 2005. A control theory model for cancer treatment by radiotherapy. International Journal of Pure and Applied Mathematics 25: 447-480.

Benzekry, S., Lamont, C., Beheshti, A., Tracz, A., Ebos, J.M.L., Hlatky, L. \& Hahnfeldt, P. 2014. Classical mathematical models for description and prediction of experimental tumor growth. PloS Computational Biology 10(8): e1003800.

Bertuzzi, A., Bruni, C., Papa, F. \& Sinisgalli, C. 2013. Optimal solution for a cancer radiotherapy problem. Journal of Mathematical Biology 66(1-2): 311-349.

Borisut, P., Khammahawong, K. \& Kumam, P. 2018. Fixed point theory approach to existence of solutions with differential equations. Differential Equations 1: 1-34.

Caputo, M. \& Fabrizio, M. 2015. A new definition of fractional derivative without singular kernel. Progress in Fractional Differentiation and Applications 1(2): 1-13.

Diethelm, K. 2003. Efficient solution of multi-term fractional differential equations using $\mathrm{P}(\mathrm{EC})^{m} \mathrm{E}$ methods. Computing 71(4): 305-319.

Diethelm, K. \& Freed, A.D. 1998. The FracPECE subroutine for the numerical solution of differential equations of fractional order. Forschung und wissenschaftliches Rechnen 1999: $57-71$.

Diethelm, K., Ford, N.J. \& Freed, A.D. 2004. Detailed error analysis for a fractional Adams method. Numerical Algorithms 36(1): 31-52.

Dokuyucu, A.M., Celik, E., Bulut, H. \& Mehmet Baskonus, H. 2018. Cancer treatment model with the Caputo-Fabrizio fractional derivative. The European Physical Journal Plus 133(3): 92.

Du, M., Wang, Z. \& Hu, H. 2013. Measuring memory with the order of fractional derivative. Scientific Reports 3: 3431.

Emami, B. 2013. Tolerance of normal tissue to therapeutic radiation. Reports of Radiotherapy and Oncology 1(1): 35-48.

Farayola, M.F., Shafie, S., Mohd Siam, F. \& Khan, I. 2020a. Mathematical modeling of radiotherapy cancer treatment using Caputo fractional derivative. Computer Methods and Programs in Biomedicine 188: 105306.

Farayola, M.F., Shafie, S., Mohd Siam, F. \& Khan, I. 2020 b. Numerical simulation of normal and cancer cells' populations with fractional derivative under radiotherapy. Computer Methods and Programs in Biomedicine 187: 105202.

Fowler, J.F. 2006. Development of radiobiology for oncology A personal view. Physics in Medicine and Biology. 51(13): R263-R286.

Freedman, H.I. \& Belostotski, G. 2009. Perturbed models for cancer treatment by radiotherapy. Differential Equations and Dynamical Systems 17(1-2): 115-133.

Garrappa, R. 2010. On linear stability of predictor-corrector algorithms for fractional differential equations. International Journal of Computer Mathematics 87(10): 2281-2290. 
Hairer, E., Lubich, Ch. \& Schlichte, M. 1985. Fast numerical solution of nonlinear Volterra convolution equations. SIAM Journal on Science and Statistical Computing 6(3): 532-541.

Jones, B. 1999. Mathematical models of tumour and normal tissue response. Acta Oncologica 38(7): 883-893.

Khalid, A.F.B., Tan, J.J. \& Yong, Y.K. 2018. Malaysian Tualang honey and its potential anti-cancer properties: A review. Sains Malaysiana 47(11): 2705-2711.

Lee, S.P., Leu, M.Y., Smathers, J.B., McBride, W.H., Parker, R.G. \& Withers, H.R. 1995. Biologically effective dose distribution based on the linear quadratic model and its clinical relevance. International Journal of Radiation Oncology, Biology, Physics 33(2): 375-389.

Liu, Z. \& Yang, C. 2014. A mathematical model of cancer treatment by radiotherapy. Computational and Mathematical Methods in Medicine 2014: Article ID. 172923.

Lokman, N., Ab. Hamid, S.A. \& Bachok, N. 2017. Survival study and prognostic factors of ovarian cancer registered in a teaching hospital in Malaysia. Sains Malaysiana 46(4): 559-565.

Losada, J. \& Nieto, J.J. 2015. Properties of a new fractional derivative without singular kernel. Progress in Fractional Differentiation and Applications 1(2): 87-92.

Nawrocki, S. \& Zubik-Kowal, B. 2015. Clinical study and numerical simulation of brain cancer dynamics under radiotherapy. Communications in Nonlinear Science and Numerical Simulation 22(1-3): 564-573.

O'Rourke, S.F.C., McAneney, H. \& Hillen, T. 2009. Linear quadratic and tumour control probability modelling in external beam radiotherapy. Journal of Mathematical Biology 58(4-5): 799-817.

Rashid, H., Mohd Siam, F. \& Maan, N. 2018. Parameter estimation for a model of ionizing radiation effects on targeted cells using genetic algorithm and pattern search method. Matematika 34(3): 1-13.

Wheeler, N. 1997. Construction and physical application of the fractional calculus. Reeds College Physics Seminar. Reeds College Physics Seminar.

Department of Mathematical Sciences

Faculty of Science

Universiti Teknologi Malaysia

81310 Johor Bahru, Johor Darul Takzim

Malaysia

*Corresponding author; email: sharidan@utm.my

Received: 27 January 2020

Accepted: 9 June 2020 